\title{
The Best Interest of the Juvenile in the Diversion Agreement within Juvenile Criminal Justice System
}

\author{
Ani Triwati \\ \{anitriwati@gmail.com \\ Faculty of Law, University of Semarang, Indonesia
}

\begin{abstract}
Restorative justice and diversion in the Juvenile Criminal Justice System are the state's policy which providing protection for juvenile conflicting with the law. Diversion using restorative justice approach is expected for resolving juvenile's cases by focusing on recovery rather than retaliation, thus preventing juvenile from processing in the criminal justice system. A diversion agreement is an approval to accomplish a case by taking into account the needs of the parties. The juvenile and / or his family strive to fulfill the diversion agreement for avoiding the criminal justice process, so that this is need investigation in order the diversion agreement is carried out with consideration of juvenile's best interests. The diversion process is implemented with forgiveness, awareness, and compensation for the victim by paying attention towards the juvenile 's ability. The failure of both diversion and its agreement implementation, resulted in the continuing criminal justice process. The legal action of juvenile in the criminal justice system creates stigmatization for juvenile. Therefore, the diversion agreement should consider the best interest for juvenile, without giving a separate burden, for achieving the goal of diversion.
\end{abstract}

Keywords: juvenile; the best interest; agreement; diversion

\section{Introduction}

Juvenile who in conflict with the law requiring special protection by the state. It is said as special protection because of necessary special action or handling by the state against juvenile facing legal problems, either as juvenile in conflict with the law (suspected of committing a criminal act), juvenile of victims or juvenile of witnesses. Special protection is carried out in relation to juvenile's limitations in the form of physically and mentally, including ways of considering in action. Thus, the handling of juvenile who are faced with the law is carried out by considering both their future and the best interests for them.

The rights of juvenile to acquire protection, including the rights of juvenile in conflict with the law, are part of the purpose of the state, which are guaranteed by the 1945 Constitution of the Republic of Indonesia. In the Criminal Justice System, the rights of juvenile in facing with the law, especially juvenile in conflict with the law, have been described in Law of the Republic of Indonesia Number 11 of 2012 concerning the Juvenile Criminal Justice System (SPPA Law). The basic substance in the SPPA Law includes regulations regarding restorative justice and diversion. Restorative justice is the settlement of juvenile's cases which is carried out by involving all parties which consists of the perpetrator and / or his family, the victim and / or his family and related parties in order to obtain a fair resolution and not retaliation, while diversion is the conversion of juvenile's cases from the 
criminal justice process. Diversion regulation with a restorative justice approach in juvenile's cases, as a more humane solution by positioning juvenile not as objects that must be penalized, but in the direction of restoration and recovery for both perpetrators and victims, so that they will have become better in future. In general, the use of the Juvenile Criminal Justice System basically is aimed to construct a fair and friendly justice system for juvenile (fair and humane) $[1]$.

Article 7 of the SPPA Law provides requirements for the implementation of diversion as a criminal act with the threat of imprisonment for under 7 (seven) years and it's not a repetition of a criminal act. Briefly it is able to say that the implementation of diversion still has several obstacles. Obstacle from substantial aspect is on the existence of limitation on the kind of criminal act in which is able to implement diversion [2]. The diversion process is executed by deliberation of diversion involving all parties (the perpetrator and / or his family, the victim and / or his family, Community Counselors, Professional Social Workers and the affected community). In this deliberation, the diversion can result either in a diversion agreement or no agreement for diversion. If there is no agreement regarding compensation during deliberation, the diversion agreement cannot be implemented and the juvenile who in conflict with the law will continue to proceed in criminal justice. Nevertheless, the diversion agreement possibly can also be made without any compensation.

Determining compensation becomes a problem in diversion deliberations when there is no agreement between the perpetrator and the victim. The amount of compensation which imbalance with the physical and psychological losses suffered by the victim or the intervention of other parties in determining the amount of compensation, will result in no agreement on diversion. The inadequacy of compensation can be caused by the inability of financial factor or unreliable nominal value, so that the juvenile (the perpetrator) cannot fulfill the demand of the victim. On the other hand, there can be the ability to provide compensation by the perpetrator but it is not followed by an awareness of the committed fault. The absence of a diversion agreement or a diversion agreement that is not implemented results in the failure of achievement in the objectives of diversion as stipulated in Article 6 of the SPPA Law, which mention the peace between victims and juvenile, resolving juvenile's cases outside the judicial process, preventing juvenile from being deprived of freedom, and encouraging the community in participating and embedding the sense of responsibility to juvenile.

A diversion agreement as a result of diversion deliberation in its implementation can be hampered or cannot be implemented due to the incapacity of the juvenile. The force approval of juvenile's part during diversionary deliberation regarding the amount of compensation, because of the concern that the juvenile would proceed in the criminal justice system. Settlement of juvenile cases in the criminal justice system has its own effect on juvenile. Apart from the stigmatization of the community, juvenile have a burden mentally because they are dealing with law enforcement officials even though various provisions have been anticipated for officers who handling juvenile cases. Stigmatization begins when juvenile enter the field of criminal justice and it has an impact on the juvenile during the process until the imposition of crime or action or even though the settlement of cases has been transferred outside the criminal court.

Diversion with a restorative justice approach requires an understanding of all parties including law enforcement officials and related institutions, so that the settlement of crimes outside the criminal justice process can be carried out by considering the best interests for juvenile. The problem, in this case, is focused on how the best interest for juvenile in the agreement of the diversion in juvenile criminal justice system. 


\section{Discussion}

\subsection{Diversion in Juvenile Criminal Justice System}

The renewal of the juvenile justice system shows better progress in solving juvenile cases. The SPPA Law as replacement of Law Number 3 of 1997 concerning Juvenile Courts, provides an opportunity to resolve juvenile's cases outside of criminal justice. The main regulation in the SPPA Law regarding diversion with a restorative justice approach which stipulated in Article 5 are expected to reduce juvenile for entering process in criminal justice. Furthermore, it is determined that diversion is carried out in the stages of investigation, prosecution and court of juvenile.

The requirements for the implementation of diversion in Article 7 of the SPPA Law have impact as diversion cannot be attempted for criminal act with the threat of imprisonment for more than 7 (seven) years and for repetition of criminal act. Nevertheless, diversion remains an important instrument in solving juvenile cases. Supreme Court Regulation Number 4 of 2014 concerning Guidelines for the Implementation of Diversion in the Criminal Justice System (Perma No.4 of 2014), Article 3 determines that judges for juvenile are obliged to demand diversion in the case that juvenile is charged with a criminal offense which has punishment of imprisonment below 7 (seven) years and is also charged with a criminal offense which has punishment of imprisonment of 7 (seven) years or more in the form of an indictment of subsidiarity, alternative, cumulative or combination (combined).

Based on the provisions of Article 3 of Perma No.4 of 2014, in court examination, diversion can be implemented for criminal act with the menace of imprisonment of more than 7 (seven) years, but also charged with committing crime which has punishment of imprisonment of less than 7 (seven) year. The transfer or settlement of cases outside the criminal court has better impact on juvenile, considering that juvenile still need guidance and supervision from parents or guardians or the state which is in this case carried out by institutes related to juvenile service and takes handling.

The diversion process through deliberation that involves all parties with concerning the interests of the victim, the welfare and responsibility of the juvenile, avoidance of negative stigma, avoidance of retaliation, and community harmony, decency, morality, and public order [3]. Deliberations in the diversion process accommodate juvenile's interests related to responsibility, avoidance of negative stigma, the interests of victims regarding both physical and psychological harms and the interests of communities affected by criminal acts. The interests of the community must be considered, because the criminal acts that have occurred basically disturbed the comfort and orderliness of community.

Diversion is carried out in every stage of examination, in this case investigators, public prosecutors and judges must consider the categories of criminal act, the age of the juvenile, the results of community research from social institution (Bapas) and the support from the environment of family and society [4]. Elucidation of Article 9 paragraph (1) determines that the lower the criminal threat, the higher the priority for diversion. Diversion is not intended to be applied against perpetrators of serious crimes, such as murder, rape, drug trade and terrorism, which have punishment by a sentence of more than 7 (seven) years. Furthermore, it also explains the priority of giving diversion and as the younger the juvenile's age, the higher the priority for diversion. Thus, the category of criminal acts in diversion is not intended for serious crimes and has a high priority on the younger age of juvenile.

The diversion process to obtain an agreement requires the approval from victim, Article 9 paragraph (2) of the SPPA Law stipulates that the diversion agreement must obtain the approval of the victim and / or the victim's family and the willingness of the juvenile and his 
family, except for criminal acts in the form of violation, minor crime, a crime without a victim or the value of the loss of victim is not more than the minimum wage of the province. Based on the provisions of Article 9 paragraph (2), there are exceptions to criminal acts that can be implemented by diversion without the approval of victim.

Referring to Article 5 of the SPPA Law regarding diversion with a restorative justice approach, there must be the approval of the victim unless there is no victim in the criminal act. The victim's approval is needed even though the criminal act is in the form of a minor offense or crime or the value of the loss is slight, this is related to the purpose of diversion, especially to instill a sense of responsibility for juvenile. Juvenile who commits a criminal act should be held responsibility in form of admitting his mistake and regretting his act with apology to the victim, unless the criminal act committed is not result in victim.

The diversion process through deliberation results in a diversion agreement in the form of peace with or without compensation, returning to the parents/guardians, participation in education or training in educational institutions or LPKS for a maximum of 3 (three) months or community service [5]. The result of the diversion agreement is conveyed by the direct superior of the official who is responsible for each level of examination to the district court in accordance with their jurisdiction within 3 (three) days since the time the agreement is reached to obtain arrangement [6].

The diversion agreement is further stated in the diversion agreement letter and it must be stipulated by the Head of the District Court in the area where the case is occurring or in the area where the diversion agreement was made (see Article 9 PP Number 65 of 2015 concerning Guidelines for Implementation of Diversion and Handling of Juvenile Not Aged 12) Year). The diversion agreement letter is the result obtained from diversion deliberation that contains the rights and obligations of all parties that do not violate the provisions of laws and regulations [7].

Deliberation in the diversion process does not always result in agreement, therefore, if there is no agreement, the juvenile's case will still be included in criminal justice. Article 13 of the SPPA Law stipulates that the juvenile criminal justice process is continued in case of the diversion process does not result in an agreement or the diversion agreement is not implemented. Thus, the juvenile case continues to proceed in the criminal court because there is no diversion agreement or the diversion agreement is not implemented.

Settlement of juvenile's cases should not be oriented towards retaliation or punishment but rather towards improvement. Providing a deterrent effect on juvenile does not mean imposing punishment, but rather acts for guidance. The SPPA Law has accommodated crimes concerning juvenile, in Article 71, which stipulates that the main crimes for juvenile consist of warning crime, conditional crime (guidance outside of institutions, community service, or supervision), job training, coaching within institutions, and jail.

Furthermore, additional punishment consists of seizing profits obtained from criminal acts or fulfilling customary obligations. Crime for deprivation of liberty is the last alternative to minimize the negative impact on juvenile. Moreover, measures for juvenile comprise of returning to their parents / guardians, handing over to someone, treatment at a mental hospital, treatment at LPKS, obligation to attend formal education and / or training held by the government or private institute, revocation of driving licenses, and / or corrections due to criminal acts [8].

These imposed measures were filed by the public prosecutor in its prosecution, except for a criminal act which has punishment by imprisonment for a minimum of 7 (seven) years [9]. Thus, the measure is only imposed on juvenile who have committed a criminal act with the threat of imprisonment for a minimum of 7 (seven) years. Diversion with a restorative 
justice approach in the children criminal justice system can reduce the number of juveniles who process in the criminal justice which gives stigmatization and the negative impact of criminal justice. In addition, the settlement of cases outside the criminal court that is carried out humanistic ally can achieve peace and hinder juvenile from being deprived of freedom.

\subsection{The Best Interest of The Juvenile in Diversion Agreement}

Diversion with a restorative justice approach is not a novelty in society and it has been implemented to date as part of problem solving in everyday life as well as it is not limited to criminal cases. The deliberative settlement bringing all parties together is carried out by confessing guilt, apology of perpetrator, forgiving from the victim and possibly being followed by compensation, aimed at obtaining a settlement that reconciles all parties and society. Representatives from the community in deliberations are needed because the social environment can be a factor that allows juvenile to commit acts of violence which in most cases are often included in the category of criminal acts (delict) [10] and society is also the recipient of the crime impact.

In the process of diversion through deliberation, confession of guilt and apology are fundamental factors, followed by forgiveness from the victim. The main requests of the victim are in the form of admission of guilt and remorse from the offender (juvenile). The perpetrator with his awareness admits his mistake and apologizes to the victim and takes responsibility for the losses suffered by the victim. Deliberation in the diversion process to obtain a fair solution will be difficult or will not reach an agreement without the awareness of the perpetrator admitting its mistaken behaviors and apologizing to the victim. Juveniles as perpetrators or juvenile in conflict with the law mostly are not aware that they have committed criminal act. The ability to think and act makes juvenile less aware of the consequences of their actions or even does not understand that their act committed is a criminal act and is detrimental for other parties.

In addition, actions that are done possibly because of following or on the order from adults. Apart from apology, forgiveness from the victim is also an opening for peace for all parties. In a scientific framework, the process of settling criminal cases in a family manner, which contains the peace of both parties, with the main foundation of forgiveness from the victim to the perpetrator is called restorative justice [11]. It is necessary to understand that the criminal act that occurs does not only focus on the perpetrator's mistake, the victim can be the cause of the crime. Restorative justice is basically a peaceful process (peacefully resolved) that involves, as far as possible, those who have involvement in certain criminal act and are collectively identified have suffering losses, and at the same time have needs and obligations with the best possible intention of restoring it as best as possible [12].

In the diversion process through deliberation apart from apology, the form of juvenile's responsibility can be followed by compensation for both physical and psychological damages. Compensation as one of the efforts to recover victims for suffering due to criminal acts. Compensation as a form of responsibility should be adjusted to the ability of the juvenile or the perpetrator, in this case the Community Advisor who conducts research can provide advice regarding the juvenile's situation. The social adviser has assignments of making community research reports for diversion purposes, providing assistance, guidance, and monitoring of juvenile during the diversion process and implementing the agreement, including reporting it to the court if diversion is not carried out [13].

The diversion agreement followed by compensation should take into account the best interests of juvenile. The ability of the juvenile or the perpetrator, the future, the physical and mental condition, the rights of the juvenile, and the recommendations of the community 
advisor are considered in the diversion agreement. The failure of diversion because there is no agreement regarding compensation shows that there is no or lack of understanding of diversion with a restorative justice approach. The victim should have realized that the compensation requested could not possibly be fulfilled due to limitation in economic factors, so that it might not be forced to fulfill it. The coercion regarding compensation agreements may result in obstruction of its implementation. The failure to implement the diversion agreement results in the inclusion of juvenile in criminal justice, so it is necessary to emphasize that deliberation in diversion does not mean of retaliation by requesting for compensation in accordance with the losses suffered, but also counting the ability of the juvenile or the perpetrator.

Some of juvenile or the perpetrators do not have the ability to provide compensation according to the victim's request. However, it does not mean that they are not responsible but it caused by economic factors. The inability to provide compensation to the victim is one of the reasons for the failure of diversion which results in juvenile proceeding to criminal justice. Victims sometimes demand compensation in the form of money with a high nominal value, which the juvenile cannot afford to fulfill. The agreement regarding compensation should be adjusted to the ability of the juvenile and not become a burden in its fulfillment.

In addition, a diversion agreement could not be reached because the victim did not want a settlement outside the criminal court. The victim's side disagrees with diversion or avoiding punishment for the reason of justice. This can be interpreted that the difference interests between all parties is fundamental problem in determining the agreement. Sometimes the victim's request cannot be fulfilled by the juvenile because the conditions offered by the victim are considered too excessive.

On the other hand, the victim does not intend to change the terms of the agreement so that the implementation of diversion is failed [14]. Diversion agreements by all parties should be carried out with awareness rather than compulsion, especially for the juvenile side who concern about proceeding in criminal justice that make them agreeing to the victim's request. Nevertheless, the diversion agreement can also be done without compensation.

The rights of juvenile in conflict with the law are accommodated in the deliberation process for diversion, so that the purpose of diversion as part of juvenile protection is achieved. Law Number 4 of 1979 concerning Juvenile Welfare, Article 6 paragraph (1) stipulates that juvenile who experience behavioral problems are provided with services and care in order to help them to overcome the obstacles that occur during their growth and development. juvenile who experiences behavior problems or juvenile who are in conflict with the law still need to survive, grow and develop according to their age, which has been guaranteed in the 1945 Constitution of the Republic of Indonesia, especially Article 28 B paragraph (2) which stipulates that every juvenile has the right for survival, growth and development and the right to protection from violence and discrimination.

Furthermore, in the Convention of Juvenile's Rights, if it is necessary and desired, measures regarding juvenile that are implemented without involving the judicial process must fulfill the requirements of human rights and legal counsel [15]. Indonesia has ratified the Convention on the Rights of the Juvenile, so that the convention becomes a guideline in regulating juvenile protection with the best interests of the juvenile as the main consideration. Actions taken for juvenile who are in conflict with the law, are carried out without entering the judicial process by considering the rights of the juvenile.

In the United Nations Standard Minimum Rules for the administration of Juvenile Justice (The Beijing Rules), rule 11.1. determines "Consideration shall be given, wherever appropriate, to dealing with juvenile offenders without resorting to formal trial by the 
competent authority, referred to in rule 14.1 below". Furthermore, determined where the case of a juvenile offender has not been diverted (under rule 11), she or he shall be dealt with by the competent authority (court, tribunal, board, council, etc.) according to the principles of a fair and just trial [16]. Diversion is an important instrument in solving juvenile's cases without involving a formal process with appropriate consideration for the interests of juvenile.

The failure of diversion or the failure to implement the diversion agreement results in the juvenile being processed in criminal justice and they will be sentenced to crime or action if they prove guilty. Data from the Directorate General of Society, Ministry of Law and Human Rights of Indonesia shows an increase number of juvenile living in LPKA. In November 2020, the number of juveniles in guidance was 1381 while in December 2020 and January 2021 it showed 1408 and 1432 juvenile respectively [17]. In the last three months there has been an increase in the number of juveniles in guidance (Juvenile Prisoners).

The increase was caused by various factors, including failed diversion, nonimplementation of the diversion agreement, the requirements for implementing diversion related to criminal acts for the threat of imprisonment for under 7 (seven) years and not a repetition of a criminal act. The diversion agreement can be said as condition for juvenile's cases to divert from the criminal justice process. Although diversion can be implemented without any compensation, compensation is the main topic discussed in the diversion deliberation for some cases.

The failed diversions owing to the absence of an agreement have contributed to the increasing number of juveniles in guidance. The awareness of all parties, community participation and research by Community Advisors are highly important in deliberations for the diversion process. The best interest for juvenile is the main consideration, considering that they are the next generation who need protection including guarantees of survival and development which suitable for their ages. The transfer of cases from criminal justice prevents juvenile from the negative impacts of criminal justice. Diversion applies primarily to the predelinquent-that is, the juvenile who exhibits the first signs of a delinquent behavior pattern. His problem or offense, usually minor, has come to the attention of the police. In the estimation, he will benefit most if further diverted from contact with delinquency and the juvenile justice system [18].

Diversion with a restorative justice approach attempt to resolve cases by gathering all parties in order to obtain fair resolution which focusing on recovery and not for retaliating. Juvenile as perpetrators of criminal acts owing to lack of thinking maturity and behave emotionally or environmental influences, in this case, also become victims so that solutions which naturally corrective and nurturing are needed. The best interests of the juvenile are the main consideration in making decisions related to juvenile, including the agreement on diversion in the juvenile criminal justice system.

\section{Conclusion}

Diversion with a restorative justice approach in the juvenile justice system is aimed to obtain fair solutions and reconciling all parties. The diversion process through deliberation is carried out by confessing guilt, apology from the perpetrator, giving forgiveness from the victim and this can be followed by compensation. The agreement regarding compensation should be adjusted to the juvenile's ability so that it does not become a burden for its 
fulfillment. A diversion agreement followed by compensation should take into account the best interests of the juvenile.

\section{References}

[1] Teguh Prasetyo, "Penerapan Diversi Terhadap Tindak Pidana Anak dalam Sistem Peradilan Pidana Anak", Refleksi Hukum, Vol. 9 No.1/ 2015.

[2] Setya Wahyudi dan Angkasa, "Application of Diversion Penal Mediation on Sexual Violence Cases to Realize Juvenile Protection for Victims of Sexual Violence", Jurnal Dinamika Hukum, Vol. 18 No. 3, September 2018.

[3] Refer to Article 8 (3) SPPA Law.

[4] Refer to Article 9 ayat (1) SPPA Law.

[5] Refer to Article 11 SPPA Law.

[6] Refer to Article 12 ayat (2) SPPA Law.

[7] Refer to PP Nomor 65 (1) Tahun 2015 number 7.

[8] Refer to Article 82 (1) SPPA Law.

[9] Refer to Article 182 (3) SPPA Law.

[10] Hulman Panjaitan, Lonna Yohanes Lengkong, Fabianustua Sihaloho, "Penerapan Diversi Terhadap Anak yang Melakukan Tindak Pidana", Tô-râ: Vol.5 No.2, Agustus 2019.

[11] Natangsa Surbakti, Peradilan Restoratif dalam Bingkai Empiri, Teori dan Kebijakan, Yogyakarta, Genta Publishing, 2015.

[12] Muladi, "Pendekatan "Restoratif Justice" dalam Sistem Peradilan Pidana dan Implementasinya dalam Sistem Peradilan Anak" (Lecture supplement in Pasca Undip dan USM), 1 November 2013, Page 3.

[13] Refer to Article 65 letter a SPPA Law.

[14] Fahmi Noor Adly, "Diversi sebagai bentuk penyelesaian perkara pidana anak di tingkat penyidikan dalam kasus kejahatan kesusilaan di wilayah hukum Polda Jawa Timur", Dialektika Vol. 15, No. 1, 2020.

[15] Refer to Konvensi Hak Anak Article 40 (3) letter b. Convention on the Right of the Juvenile

[16] Refer to Rule 14.1 United Nations Standard Minimum Rules for the administration of Juvenile Justice (The Beijing Rules).

[17] Ditjenpas, "Data Terakhir Jumlah Penghuni Perkanwil" Bulan November 2020, Desember 2020, Januari 2021(http://smslap.ditjenpas.go.id/public/grl/current/monthly).

[18] Alan R. Coffey, Juvenile Justice as a System Law Enforcement to Rehabilitation, (Toronto: Prentice-Hall. Inc, 1974) 